\section{How linear is growth?}

\section{Sir,}

With great interest we read the article by Wales and Milner on linear growth. ${ }^{1}$ We have been using this technique for over three years, and we have surveyed more than 20000 measurements of the lower leg length (each of these measurements consisting of at least four lower leg length estimations) in more than 300 children, about 80 of these being healthy and measured regularly at weekly or half weekly intervals for periods between three months and two years. Thus we are pleased to see that the authors have found results which are very similar and almost undistinguishable from our data. We have not yet published all our results for several reasons.

In the beginning we tried to use knemometry for the assessment of linear growth, hoping to find means to predict linear growth rates in much shorter intervals than hitherto possible. We gave up this aim for exactly the reasons published by Wales and Milner: it is not possible. The authors found an irregular pattern of lower leg growth from week to week which was explicable in some children, as they had short illness or underwent tonsillectomy, but not in all of them.

We have shown earlier that lower leg growth indeed is non-linear in many children, ${ }^{2}$ and this has been confirmed by Wit et al. ${ }^{3}$ Moreover, we have evidence that there is a regular pattern of lower leg growth in many if not in almost all children, which consists of short periods of rapid growth followed by periods of growth arrests every 30 to 55 days, and which we named 'mini-growth-spurts' (Hermanussen M, Geiger Benoit K, Sippell W G, unpublished observations). Therefore, whenever one starts to measure lower leg length at weekly intervals, it has to be shown by the following measurements at what part of the "mini-growthspurts' the child momentarily grows: in the case of maximal growth velocity extrapolation of such a growth rate will overestimate the mean linear increment of a longer interval, and vice versa. Fig 2 of the article by Wales and Milner provides some perfect examples of 'mini-growthspurts' that could not have been better measured. If the authors had measured these children longer they would have found not just one single irregular pattern of lower leg growth but most probably something similar to what we termed 'mini-growth-spurts'. They would then have given their article a different title as lower leg growth is non-linear in many cases and thus cannot be used for the assessment of linear growth.

As it is much more difficult to measure total body height with comparable accuracy, it still remains to be elucidated whether total body growth is, indeed, linear. In view of the scant knowledge on short term body height increments, it is, in fact, questionable, and linearity of total body growth may also be just an assumption, as this was true for lower leg growth before we had evidence to the contrary. The unpredictability of half annual growth rates by monthly measurements as shown in Table 5 of the article by Wales and Milner being rather similar to the findings by knemometry may, indeed, indicate that we overestimate the error of height measurements, and that there is also pronounced non-linearity of total body height increments.
In this event all the irregularities of height measurements throughout the years-mostly discarded as "error of the measurement'-could, indeed, have given some valuable hint which was neglected because it did not fit into our 'weltanschauung' of linearity of short term growth.

\section{References}

1 Wales SKH, Milner RDG. Knemometry in assessment of linear growth. Arch Dis Child 1987:62:166-71.

2 Hermanussen M. Sippell WG. Changes of short term growth velocity (mini-growth-spurts) in 36 healthy children. measured twice weckly by knemometry. Ann Hum Biol 1985:12: (Suppl I):79.

3 Wit JM, van Kalsbeek EJ, van Wijk-Hock J, Lepping GJ. Assessment of the usefulness of weekly knemometric measurements in growth studies. Ped Research 1986;20:1196.

\section{Hermanussen Endocrine Unit, Children's Hospital, University of Kiel, West Germany}

\section{Club foot}

Sir,

I was sorry to find in the annotation on club foot no reference to the part which occult spinal dysraphism sometimes plays in the diagnosis and, more importantly, in the management of this malformation of the foot. This omission is surprising as so much has been published in the past 20 years, providing evidence of the occasional lower limb deterioration when the spinal lesion is not recognised and attended to. Unilateral club foot, and especially a small foot, are among the most common clues to the presence of a spinal malformation, which should therefore be sought by inspection and (usually) plain radiography of the spine. I realise that an annotation is necessarily a brief review of a subject. As there was room for emphasising the limited success of treatment of the foot, I think there was space for mentioning one of the occasional causes of failure.

\section{Reference \\ ' Klenerman L. Club Foot. Arch Dis Child 1987;62:112-3.

$$
\begin{array}{r}
\text { KenNeTH TILL } \\
\text { Reed's Court, } \\
\text { Lydeard St Lawrence, } \\
\text { Taunton, } \\
\text { Somerset TA4 3RX }
\end{array}
$$

\section{Dr Klenerman comments:}

The reason for omitting mention of the neurological aspect of club foot was that I was confining my attention to the so called idiopathic club foot, which is the commonest variety; and in mentioning that diagnosis was easy, I was emphasising the point that prognosis is more difficult in this particular condition. 